Article

\title{
People's Perception of Experimental Installations for Sustainable Energy: The Case of IFMIF-DONES
}

\author{
Zaida Troya ${ }^{1}$, Rafael Esteban ${ }^{1}\left[\right.$, Enrique Herrera-Viedma ${ }^{1}$ (D) and Antonio Peña-García ${ }^{2, *(1)}$ \\ 1 “DONES Preparatory Phase" Project (CE Ref. 870186), Vicerrectorate of Research, University of Granada, \\ 18071 Granada, Spain; zaidatroya@correo.ugr.es (Z.T.); rafaelesteban@ugr.es (R.E.); \\ viedma@decsai.ugr.es (E.H.-V.) \\ 2 Department of Civil Engineering, University of Granada, 18071 Granada, Spain \\ * Correspondence: pgarcia@ugr.es; Tel.: +34-958-249435
}

Citation: Troya, Z.; Esteban, R.;

Herrera-Viedma, E.; Peña-García, A. People's Perception of Experimental Installations for Sustainable Energy: The Case of IFMIF-DONES.

Sustainability 2022, 14, 899. https:// doi.org/10.3390/su14020899

Academic Editors: Elena Cristina Rada and Lucian-Ionel Cioca

Received: 3 November 2021

Accepted: 12 January 2022

Published: 13 January 2022

Publisher's Note: MDPI stays neutral with regard to jurisdictional claims in published maps and institutional affiliations.

Copyright: () 2022 by the authors Licensee MDPI, Basel, Switzerland. This article is an open access article distributed under the terms and conditions of the Creative Commons Attribution (CC BY) license (https:// creativecommons.org/licenses/by/ $4.0 /)$.

\begin{abstract}
Nuclear facilities are a main milestone in the long way to sustainable energy. Beyond the well-known fission centrals, the necessity of cleaner, more efficient and almost unlimited energy reducing waste to almost zero is a major challenge in the next decades. This is the case with nuclear fusion. Different experimental installations to definitively control this nuclear power are proliferating in different countries. However, citizens in the surroundings of cities and villages where these installations are going to be settled are frequently reluctant because of doubts about the expected benefits and the potential hazards. In this framework, knowing the opinion of people and their perception of experimental fusion facilities is essential for researchers, administrations and rulemaking bodies planning future fusion plants. This is the case for IFMIF-DONES, a neutron irradiation facility to determine the most suitable materials for the future fusion reactors. The construction of this installation is starting in Escúzar (Granada, Spain), and this work presents a large survey among 311 people living or working in the village. Their perception, fears, hopes and other variables are analyzed, and the conclusions for future installations and their impact on the energy policy are presented.
\end{abstract}

Keywords: sustainable development; psychosocial risks; socioeconomic impact; nuclear facilities

\section{Introduction}

A lot of attention has been paid to energy sources that can contribute to Sustainable Development from all perspectives, as defined in the Brundtland Report, that is, the "development that meets the needs of the present without compromising the ability of future generations to meet their own needs" [1]. Among these needs, clean energy allowing industrial production, transport and other is essential [2].

Although the concerns related to clean energy itself are clear and well established (environmental protection, well use of resources and raw materials, economic savings etc.), it is not so clear how the pursuit of clean energy can affect people.

In this sense, nuclear power is a matter of concern whose classification as a "green energy source" is currently under consideration by the European Commission. This body bases its arguments on the Joint Research Center (JCR) report on Technical assessment of nuclear energy with respect to the "do no significant harm" criteria of Regulation (EU) $2020 / 852$ [3]. Beyond these considerations, nuclear fusion is expected to overcome the main disadvantages of the currently used nuclear fission, especially in matters of waste management and the availability of Uranium and Plutonium.

However, the path towards the control of nuclear fusion is a paradigm of extremely complex research and very expensive experimental infrastructures like the "International Thermonuclear Experimental Reactor" (ITER), the world's largest fusion experiment whose target is proving the feasibility of fusion as a large-scale and carbon-free source of energy [4], 
and the "International Fusion Materials Irradiation Facility-Demo Oriented NEutron Source" (IFMIF-DONES) [5].

In this framework, it is essential to investigate how these large experimental infrastructures will impact on their surroundings from all the possible perspectives: social, economic, cultural and many others [5,6].

In addition, a successful implementation of nuclear experimental facilities like ITER and IFMIF-DONES (the target of this work) in their geographical and socioeconomic context does not depend only on the objective abovementioned factors; it is also important to make sure that people living and working around will feel safe and free of uncertainties that could impact their health and well-being. If that were the case, infrastructures like those would not foster, but impair Sustainable Development due to massive migration, abandonment of the activities and main services in the zone, etc. [7].

In this work, the perceived psychosocial risks and other socioeconomic-related perceptions of the inhabitants of the zone where IFMIF-DONES is going to be built, are evaluated. The infrastructure, the geographical and human framework, the methods used to evaluate the perceived risks and the results after extensive survey among 311 participants will be presented and analyzed.

\subsection{The International Fusion Materials Irradiation Facility-Demo-Oriented NEutron Source (IFMIF-DONES)}

The need for more and more energy to ensure economic growth and resources for everyone without harming the environment makes both the scientific community and governments around the world work hard to control nuclear fusion and thus profit from its huge benefits.

Although there are large international experiments running or near to starting to work $[4,8]$, serious technical problems in the long way towards the control of fusion energy still remain. In addition to the control of plasmas at about $150 \mathrm{MK}$, the control of the produced neutrons that cannot be stopped with magnetic fields is one of the main problems.

The aim of IFMIF-DONES is to obtain neutrons like those to be produced in real fusion reactions and irradiate different materials in order to know which one or ones are the most suitable for the construction of the future fusion reactors $[9,10]$. This project has been acknowledged as critical in the path towards the control of nuclear fusion for years; it was definitively legislated and its objectives, scope, limits and finality, defined in the Broader Approach between the European Atomic Energy Community (EUROATOM) and the Government of Japan [11].

This unique experimental scientific facility has started to be built in Escúzar (Province of Granada, South of Spain) (Figure 1). The initial budget of the Project is about $700 \mathrm{M} €$ that will be mainly funded by the European Regional Development Fund [12], EUROfusion [13] and other European programs, as well as national funds from other programs [14]. In spite of the typical challenges to set up such complex scientific infrastructure (project management, funds acquisition, construction, future maintenance etc.), its interaction with people living and working near its location is a major concern. Indeed, it is not enough that the neighbors will enjoy better infrastructures and a higher level of incomes: they must also feel comfortable with the infrastructure itself and the changes that it will bring to their traditional way of life.

Among these circumstances, the perceived risks coming from IFMIF-DONES is one of the most important since a negative perception could even lead people to leave the area, which would cause the opposite effect than is intended and consequences for the Sustainable Development of the zone.

In the next item, some basic concepts about psychosocial perceived risks will be presented in order to introduce one of the main novelties of this work. 


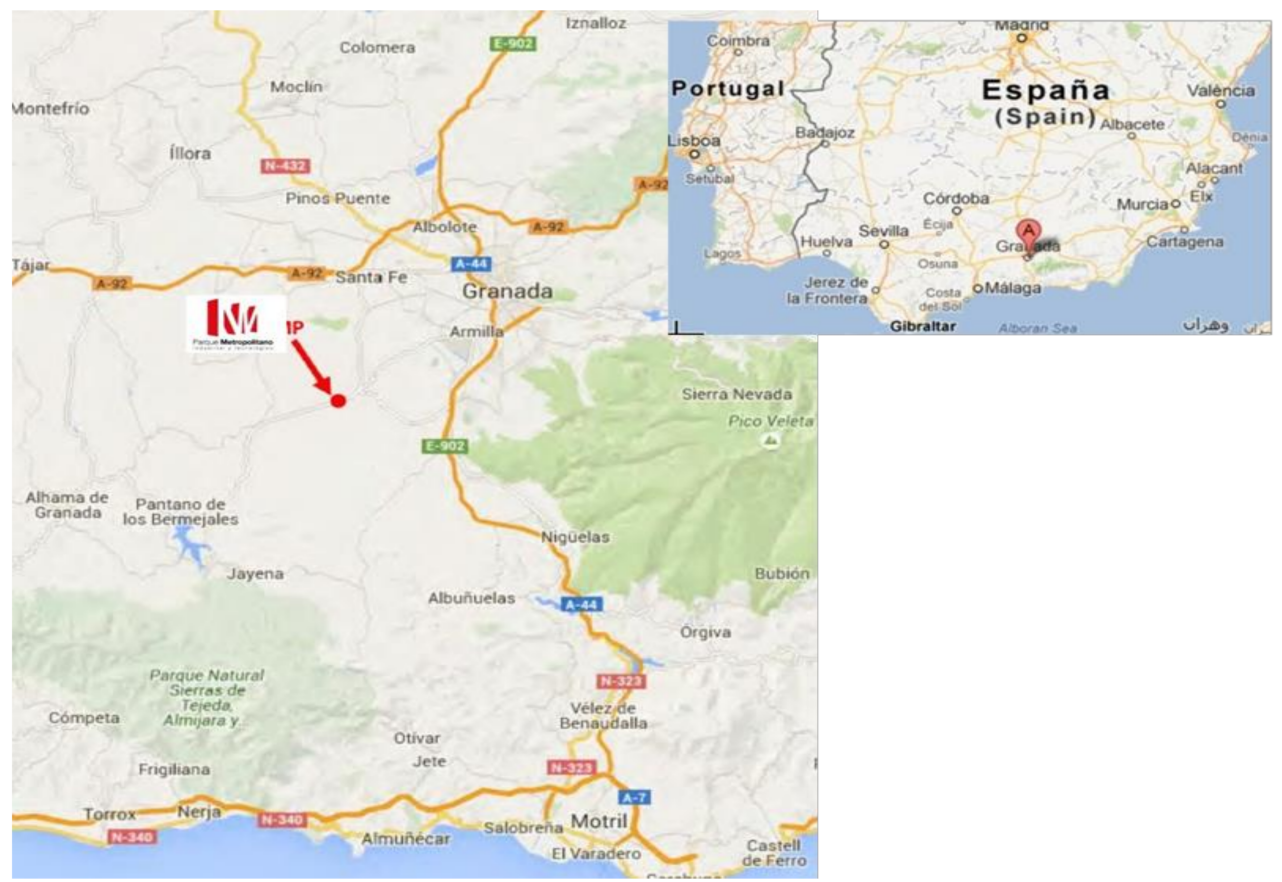

Figure 1. Geographical location of IFMIF-DONES (Escúzar-Granada, Spain).

\subsection{Perceived Psychosocial Hazards}

The concept of "psychosocial hazards" refers to aspects relating our social environment and their consequences on our health and wellbeing. It is generally associated to the labour environment, mainly focused on the negative interrelationship between working conditions and the human factors [15].

Some of the first documents approaching psychosocial hazards in depth came from the International Labour Organization (ILO) [16], which in 1984, together with the World Health Organization (WHO) defined them as "the interactions between and among work environment, job content, organizational conditions and workers' capacities, needs, culture, personal extra-job considerations that may, through perceptions and experience, influence health, work performance and job satisfaction" [17]. Later, it was explained how each factor impacts the workers in a different way according to their individual perception.

In parallel, the shift from the agricultural and industrial sectors to the production of services and other new activities narrowly linked to the wide concept of Sustainable Development [1] is the basis for new psychosocial risks, real and perceived. These are the aim of this research.

In this context, it is important to distinguish between safety (or hazard) and perceived safety (or hazard). Evaluating the perception of safety and potential psychosocial hazards among the people living or working near critical installations such as factories, power plants, experimental facilities and others, is a key factor to prevent the negative impacts of these installations on people's physical and mental health.

The evaluation of perceived safety in streets and other civil infrastructures [18-21], and also in nuclear plants producing energy from fission [22-27], are fields of active research, widely approached in the literature, whilst the perceived psychosocial hazards in experimental facilities devoted to testing new ways of energy production are scarcely studied. The choice of a survey for their evaluation is a feasible and useful tool that allows people to express their opinion so that Public Administrations can plan special projects without negative impact on people living in the surroundings.

\section{Materials and Methods}

A survey with 37 items (original in Spanish in Appendix A) [28] was carried out among 311 citizens and workers in Escúzar (Granada), with the target of studying their 
perception of IFMIF-DONES in aspects such as perceived safety, and economic and social impact. The necessity of the survey was pointed out by the management of the Project DONES Preparatory Phase (Ref. 870186) and accepted by the European Commission, which is the funding body [22]. The questions were designed between physicists working on the project, economists and local authorities and finally validated by specialists in methodology. The pollsters were paid and had specific training and good knowledge of the population to be asked.

All the inhabitants of Escúzar were invited to freely participate, so the number of respondents (almost 50\% of the population) is a good indicator of the concern of the population with the project.

Non personal data questions are binary-type (no/yes) or "no/I don't know/yes". The questions are graded no $=-1, \mathrm{I}$ don't know $=0$ and yes $=1$. When questions are part of a more general scale, an instrumental variable is built simply adding the codes for each item. For instance, a scale with 4 items will be graded from $[-4,4]$.

For binary response dependent data, a logistic regression model [29] was performed. For discrete (more than 7-point scale) response-dependent data, an ANCOVA model [30] was applied.

From the perspective of order and methodology of administration to people, the items are divided into five blocks (without informing the asked people about such division). These blocks follow a first one concerning some personal data.

1. Personal data: gender, age, children, training and professional activity (5 items).

2. General knowledge about IFMIF-DONES project (4 items).

3. Specific knowledge about energy and nuclear facilities (6 items).

4. Socio-economic aspects of the project (12 items).

5. Perceived Safety (6 items).

6. Information about the interest and general opinion of the project (4 items).

However, during the statistical analysis, the questions excluding personal data were grouped in a slightly different way, as shown in Table 1.

Table 1. Questions in English grouped.

\begin{tabular}{|c|c|c|c|}
\hline Group & Scale & Label & Question \\
\hline \multirow{5}{*}{ Previous information } & Yes/No & inform1 & With the information you have, do you understand what is going to be done? \\
\hline & Yes/No & inform2 & Do you know what nuclear power is? \\
\hline & Yes/No & inform3 & Do you know the difference between nuclear fission and fusion? \\
\hline & Yes/No & inform4 & Do you know about the importance of nuclear fusion? \\
\hline & 3-point & impact1 & Do you think that the fusion energy is a tools against the climate change? \\
\hline \multirow{3}{*}{$\begin{array}{l}\text { General impact of the } \\
\text { infrastructure }\end{array}$} & 3-point & impact2 & $\begin{array}{l}\text { Do you think that IFMIF-DONES will be a key element to develop an alternative source of } \\
\text { energy that does not consume fossil resources, environmentally friendly and unlimited? }\end{array}$ \\
\hline & 3-point & impact3 & Do you think that IFMIF-DONES will have a great technological and scientific impact? \\
\hline & 3-point & impact4 & Did you know that IFMIF-DONES is designed to investigate at long term about 35 years? \\
\hline \multirow{11}{*}{ Economic impact } & 3-point & impact5 & Do you think that Escúzar can contribute to solve the energy problems of Mankind? \\
\hline & 3-point & econ1 & Do you think it is an opportunity to create jobs for Escúzar inhabitants? \\
\hline & 3-point & econ2 & Do you think that it will contribute to stable and qualified employment for future generations? \\
\hline & 3-point & econ3 & $\begin{array}{l}\text { Do you think that this project will benefit the business sector of Escúzar and that new } \\
\text { companies to supply goods and services will be created? }\end{array}$ \\
\hline & 3-point & econ 4 & $\begin{array}{l}\text { Do you think that there will be a change in the economic model of Escúzar based on } \\
\text { knowledge, technology and research? }\end{array}$ \\
\hline & 3-point & econ5 & Do you think that the town will increase its economic activity with this infrastructure? \\
\hline & 3-point & econ6 & $\begin{array}{l}\text { Do you think that the increase in incomes from taxes, licenses and other will improve the } \\
\text { quality of life of the inhabitants? }\end{array}$ \\
\hline & 3-point & econ7 & High qualified technical profiles will be hired. Do you think that it will generate incomes? \\
\hline & 3-point & econ8 & $\begin{array}{l}\text { Have you thought that there will be stays of international researchers visiting the facility and } \\
\text { thus the number of visitors with high socioeconomic level in the town will increase? }\end{array}$ \\
\hline & 3-point & econ9 & Do you foresee an improvement in the communication, transport and energy infrastructures? \\
\hline & 3-point & econ10 & $\begin{array}{c}\text { Do you think that the security in the town will increase (security services, more policemen) } \\
\text { thanks to the infrastructure? }\end{array}$ \\
\hline
\end{tabular}


Table 1. Cont.

\begin{tabular}{|c|c|c|c|}
\hline Group & Scale & Label & Question \\
\hline \multirow{4}{*}{ Safety of infrastructure } & 3-point & segur1 & Do you think that the design of IFMIF-DONES is accurate and fulfills all the safety measures? \\
\hline & 3-point & segur2 & Will you avoid to get near the facility and/or decrease the time of exposure there? \\
\hline & 3-point & segur3 & Do you think it can cause discomfort and lack of safety in the town? \\
\hline & 3-point & segur4 & Do you think that a first aid station should be open in Escúzar once the facility is built? \\
\hline \multirow{3}{*}{ Training neccesity } & 3-point & formac1 & If a training session directed to the inhabitants of Escúzar were celebratedwould you attend? \\
\hline & 3-point & formac2 & $\begin{array}{c}\text { Do you think that the information campaign carried out by the Town Hall to explain the } \\
\text { project up to date is enough? }\end{array}$ \\
\hline & 3-point & formac3 & Would you like that the media devoted more, more detailed and clearer information? \\
\hline
\end{tabular}

For the statistical analysis, the answers yes/no/I don't know are codified with the values $-1,0$ and 1 respectively. Then, an inner consistency analysis was carried out for the groups in Table 1. For each of these groups, an instrumental variable was created with an interval comprising the sum of all possible values. For example, in the group "Previous information", with 4 questions, the interval is $[-4,4]$. Most conclusions of this work have been taken from the analysis of these variables. Before the instrumental variables were built, an internal consistency analysis for the scale was made. Items that lead to a low internal consistency were removed. Additionally, items with reverse scales were checked and recoded.

\section{Results}

After the first round of surveys to 311 male and female participants, the main findings of their analysis are presented.

In order to establish the general framework where the survey has been carried out, some data of the population in Escúzar are shown in Table 2.

Table 2. General data of population in Escúzar (Granada, Spain).

\begin{tabular}{ccc}
\hline & 2020 Census & Survey \\
\hline Female & $381(48 \%)$ & $173(56 \%)$ \\
Male & $410(52 \%)$ & $138(44 \%)$ \\
Age & & \\
$20<$ Age $<65$ & $488(75 \%)$ & $277(92 \%)$ \\
Age $>65$ & $163(25 \%)$ & $24(8 \%)$ \\
Studies & & \\
No studies or basic & - & 136 \\
High school & - & 81 \\
University & - & 94 \\
Source & & 142 \\
It is said (rumors) & & 44 \\
Press & & 53 \\
TV & & 53 \\
Internet \& Social Net. & & 4 \\
Radio & & 15 \\
Other & &
\end{tabular}

Table 2 shows that there is a slightly higher number of women with respect to the gender distribution of the population. This excess is not considered as a matter of bias. The rest of the values for the variables (age and labour situation) confirm that the surveyed sample has an acceptable coupling with the real census, so it is representative of the population under study.

Most of those surveyed (516) had heard about the Project (96.7\%) and 89.0\% confirmed living near the future facility. Table 3.

The results after analyzing the instrumental variables created by gender are shown in 
Table 3. Analysis of instrumental created variables by gender.

\begin{tabular}{ccccc}
\hline & Average & SD & Error & Sig \\
\hline Information & 0.6389 & 2.7381 & 0.1863 & 0.257 \\
Impact & 2.1806 & 1.8375 & 0.1250 & 0.464 \\
Economy & 6.8426 & 4.0374 & 0.2747 & 0.712 \\
Perceived Safety & -0.0926 & 1.6874 & 0.1148 & 0.505 \\
Formation & 1.6157 & 1.2145 & 0.0826 & 0.927 \\
\hline
\end{tabular}

Perceived safety deserved a special analysis since it has not been studied in the literature concerning scientific installations so far. For these instrumental variables we build an ANCOVA model for several factors and instrumental variables. The only significant factors and covariables are shown in Table 4.

Table 4. Analysis of instrumental variable "perceived safety".

\begin{tabular}{ccccc}
\hline Factors & Squares Sum & Average Square & F & $p$ \\
\hline Gender & 12.93 & 12.927 & 5.889 & 0.016 \\
Impact & 85.14 & 85.143 & 38.788 & $<0.001$ \\
Economy & 37.81 & 37.814 & 17.227 & $<0.001$ \\
Residuals & 1097.53 & 2.195 & & \\
\hline
\end{tabular}

As shown, only variables "Impact" and "Economy" are statistically significant to explain the perceived safety in a direct way, that is, higher values in "Impact" or "Economy" lead to higher values in perceived safety. Regarding gender, women had higher values for perceived safety than men.

\section{Discussion}

The increasing energy demands due to many factors like the quick growth of highly populated countries, and the difficulties linked to some types of fuels (fossil but also nuclear) is impacting the prices of energy and the pollution due to higher production. Both factors lead Mankind to wide uncertainty and in more and more cases, to so-called "energy poverty", a major concern of the European Commission and other international bodies [31], and, of course, to a negative environmental impact.

Both effects, energy poverty and environmental impact, directly affect almost all the SDGs, whose achievement will be critical in the coming years. For this reason, the study of experimental facilities contributing to a cleaner energy seems to be critical from all perspectives, including social, economic and many others.

The research presents the results of a field study on knowledge on energy, information and the socioeconomic impact of energy-related experimental facilities, and perceived psychosocial hazards among the inhabitants of a small town in the south of Spain. Concretely, it was carried out in the town of Escúzar (Province of Granada), a rural and poorly developed area where the next construction of the "International Fusion Materials Irradiation Facility-Demo Oriented NEutron Source" (IFMIF-DONES), is going to be built. It is expected to become the most important infrastructure for the testing of materials for nuclear fusion reactors, and it is supposed to boost the local economy and create a social shift from a rural society to a knowledge-based one where young people do not have to look for qualified jobs to big cities, but stay in their town if they want, thus fostering the local development without breaking the equilibrium of population between urban and rural areas.

The foreseen benefits of IFMIF-DONES are expected to contribute to the achievement of several SDGs for two reasons:

(1) This facility will be a key milestone towards clean energy with almost-zero emissions.

(2) It will bring better quality of life from material, cultural and social perspectives. 
However, all these benefits and contributions to Sustainable Development would be useless if the perspective of the people living near this large installation were ignored. Thus, a survey with 37 questions was elaborated and answered by 311 inhabitants. The design of the survey was carried out by a team of researchers in deep contact with the Technical Direction of the Project and the local Authorities, so that the particularities from both technical and social perspectives were fully considered in the survey, thus achieving a more complete understanding of the feeling of the people.

Among the main findings after the survey analysis are the following:

(1) Women seem to have less fear to eventual safety problems than men. The explanation for this result needs more reflection and should be a matter of future research.

(2) The higher the level of studies, the lower the concern on safety issues. This can be due to deeper knowledge on modern experimental facilities and higher trust in scientists and engineers.

(3) The higher the trust in the economic fostering of IFMIF-DONES in the area, the lower the concern about risks. This trend may respond to the balance between economic needs and assumed risks, which is often strongly linked to socioeconomic status: the higher the economic necessity, the lower the fear.

A second round of this survey is planned with the target of studying the evolution of Escúzar inhabitants' perception and, hence, help to foresee future trends and paradigms for this and other experimental installation dealing with clean and sustainable energy.

Author Contributions: Conceptualization, A.P.-G.; methodology, Z.T. and R.E.; formal analysis, Z.T.; investigation, Z.T., R.E., E.H.-V. and A.P.-G.; resources, E.H.-V. and A.P.-G.; data curation, Z.T.; writing-original draft preparation, Z.T. and R.E.; writing-review and editing, Z.T., R.E. and A.P.-G.; supervision, E.H.-V. and A.P.-G.; project administration, Z.T.; funding acquisition, E.H.-V. and A.P.-G. All authors have read and agreed to the published version of the manuscript.

Funding: This research and the APC were funded by the European Commission as part of the Project “DONES Preparatory Phase" (Ref. 870186).

Acknowledgments: The authors thank Antonio Arrabal, Major of Escúzar, for his support, and Pedro García, Full Professor in Statistics, for his wise advertisement in data analysis.

Conflicts of Interest: The authors declare no conflict of interest. 


\section{Appendix A}

CULTAD DE

PCLLCIONES LABORALES

$Y$ RECURSOS HUMANOS

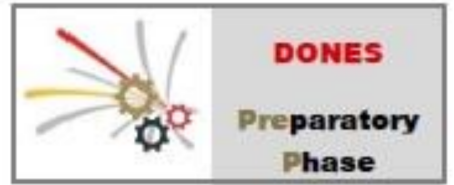

Título de la investigación: "Cuestionario medidor de la percepción del impacto económico, social y de riesgos psicosociales en el entorno de la instalación de la Infraestructura de IFMIF-DONES ESPAÑA (Granada)".

Herramienta de recogida de datos - cuestionario semi estructurado aplicado a la población del entorno de la instalación de la infraestructura IFMIF-DONES. Actividad llevada a cabo en el marco del proyecto "DONES Preparatory Phase" financiado por la Comisión Europea (Ref. 870186).

Tiene como objetivo medir la percepción del impacto económico y social. Toda la información se utilizará de forma exclusiva para los objetivos descritos.

Se trata de un cuestionario ANÓNIMO, de respuesta VOLUNTARIA, por lo que te pedimos que, en el espacio a continuación, introduzcas las iniciales de tu nombre y apellidos y las dos últimas cifras de tu año de nacimiento (ej: José Manuel Pérez García, 1986: JMPG86)

Debe señalar la opción de respuesta con una " $\mathrm{X}$ ", en la que considere que describe mejor su situación.

Gracias por su colaboración.

\section{IDENTIFICACIÓN}

1) Sexo: $M$

2) Edad:

3) ¿Tiene usted hijos? Si $\square$ No

4) Formación:

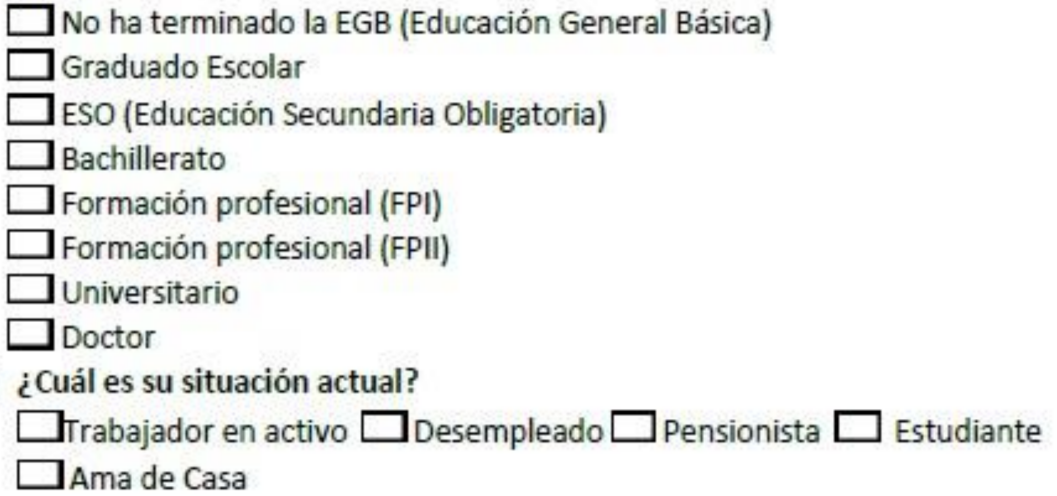

Figure A1. Cont. 


\section{CONOCIMIENTO}

6) ¿Ha oído hablar del proyecto para la implementación del acelerador de partículas IFMIF-DONES en Escúzar? Si $\square$ No $\square$

7) ¿Su casa o centro de trabajo está cerca de la infraestructura? Sí $\square$ No $\square$ Nolosé $\square$

8) ¿Cuál es la principal fuente de comunicación por la que ha recibido información de IFMIF-DONES?

$\square$ se rumoreaba en el entorno

$\square$ Prensa escrita

$\square$ Televisión

$\square$ Internet (Facebook, Twitter, páginas webs)

$\square$ Radio

$\square$ otros

9) Con la información que ha recibido ¿entiende lo que se va a realizar? si $\square$ No $\square$

\section{CONOCIMIENTO ESPECÍ́FICO}

10) ¿Sabe qué es la energía nuclear? si $\square$ No $\square$

11) ¿Conoce la diferencia entre fisión y fusión nuclear? si $\square$ № $\square$

12) ¿Conoce la importancia de la fusión nuclear? Si $\square$ № $\square$

13) ¿Considera que la energía de fusión nuclear es un instrumento para la lucha contra el cambio climático? Si No

No lo sé $\square$

14) ¿Considera que IFMIF-DONES será un elemento esencial para desarrollar una fuente de energía alternativa que no consuma recursos fósiles, respetuosa con el medioambiente e ilimitada? si $\square$ No $\square$ No lo sé $\square$

15) ¿Piensa que IFMIF-DONES va a generar un gran impacto tecnológico y científico? sí $\square$ No $\square$ No lo sé $\square$

\section{ASPECTOS SOCIO-ECONÓMICOS}

16) ¿Conocía que IFMIF-DONES es una instalación creada para investigar a largo plazo por un periodo de 35 años? Sí No $\square$ No lo sé

17) $¿$ Considera que es una oportunidad para generar puestos de trabajo entre los habitantes de la población de Escúzar? Si $\square$ № $\square$ No lo sé $\square$

18) ¿Cree que a largo plazo contribuirá al empleo estable y cualificado de futuras generaciones? sí $\square$ No $\square$ No lo sé $\square$

19) ¿Cree que este proyecto beneficiará al sector empresarial de Escúzar y que se crearán empresas proveedoras de bienes y servicios del mismo?
Sí $\square$ No
No lo sé

20) ¿Considera que se producirá un cambio de modelo económico en Escúzar basado en el conocimiento, tecnología y la investigación?

sí $\square$ No $\square$ No lo sé $\square$

Figure A1. Cont. 
21) ¿Cree que la localidad obtendrá un aumento de la actividad económica con dicha instalación? Si

No $\square$ Nolo sé $\square$

22) ¿Considera el incremento de tributos, licencias de obras, impuestos, etc. repercutirá en la mejora de la calidad de vida de los vecinos?

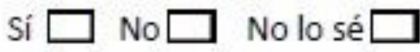

23) ¿Piensa que Escúzar puede aportar algo a resolver los problemas energéticos de la humanidad? si $\square$ No $\square$ No lo sé $\square$

24) Se contratarán perfiles tecnológicos altamente cualificados, ¿Considera que atraerá riqueza? Si $\square$ № $\square$ No lo sé $\square$

25) ¿Ha pensado en que se realizarán estancias de investigadores a nivel internacional que pasarán por la instalación y por tanto aumentará el número de visitantes de alto nivel socioeconómico en la localidad?

sí $\square$ No $\square$ Nolo sé $\square$

26) ¿Piensa que habrá una mejora en infraestructuras de transporte, comunicaciones, energética, etc.? Si $\square$ № $\square$ Nolo sé $\square$

27) ¿Considera que aumentará la seguridad en la localidad (servicios de seguridad y vigilancia, aumento de efectivos) debido a la infraestructura?

sí $\square$ No $\square$ Nolo sé $\square$

\section{SEGURIDAD}

28) ¿Conoce o está informado de posibles aspectos negativos de la implantación de esta infraestructura? si $\square$ № $\square$ No lo sé $\square$

29) En caso afirmativo, diga por orden qué aspectos negativos:

1.-

2.-

3.-

30) ¿Considera que el diseño de IFMIF-DONES es idóneo y cumple con todas las medidas de seguridad? si $\square$ No $\square$ No lo sé $\square$

31)¿Evitará el acercamiento y/o reducirá el tiempo de exposición ante la infraestructura? si $\square$ No $\square$ No lo sé $\square$

32) ¿Cree que puede provocar malestar e inseguridad en el pueblo?

sí $\square$ No $\square$ No lo sé $\square$

33) ¿Considera que debería abrirse un puesto de primeros auxilios en Escúzar una vez instalado el acelerador de partículas?

Si $\square$ No $\square$ No lo sé $\square$

Figure A1. Cont. 


\section{INFORMACIÓN}

34) En el caso de que se haga una jornada de formación y de concienciación sobre el proyecto a la población de Escúzar, ¿ estaría interesado en asistir?

Sí $\square$ No $\square$ Nolosé $\square$

35) ¿Le parece suficiente la campaña de información llevada a cabo hasta ahora por el Ayuntamiento para dar a conocer el proyecto en Escúzar?

Sí $\square$ No $\square$ No lo sé $\square$

36) ¿Le gustaría que los medios dedicasen más información, más detallada y de forma más clara? si $\square$ No $\square$ Nolo sé $\square$

37) Con el conocimiento que tiene hasta el momento, ¿apoya la instalación del proyecto? sí $\square$ No $\square$ Nolo sé $\square$

\section{Por favor, a continuación, indíquenos de manera general cuál es su opinión sobre la implantación del acelerador de partículas:}

Figure A1. Original survey (in Spanish).

\section{References}

1. World Commission on Environment and Development. Our Common Future; Oxford University Press: Oxford, UK, 1987.

2. Lund, H. Renewable energy strategies for sustainable development. Energy 2007, 32, 912-919. [CrossRef]

3. Abousahl, S.; Carbol, P.; Farrar, B.; Gerbelova, H.; Konings, R.; Lubomirova, K.; Martin Ramos, M.; Matuzas, V.; Nilsson, K.; Peerani, P. Technical Assessment of Nuclear Energy with Respect to the 'Do No Significant Harm' Criteria of Regulation (EU) 2020/852 ('Taxonomy Regulation'); EUR 30777 EN; Publications Office of the European Union: Luxembourg, 2021 ; ISBN 9789276405382. [CrossRef]

4. International Thermonuclear Experimental Reactor (ITER) website. Available online: https://www.iter.org/ (accessed on 21 October 2021).

5. Fernández-Pérez, V.; Peña-García, A. The Contribution of Peripheral Large Scientific Infrastructures to Sustainable Development from a Global and Territorial Perspective: The Case of IFMIF-DONES. Sustainability 2021, 13, 454. [CrossRef]

6. Esteban-López, R.; Troya, Z.; Fernández-Pérez, V.; Peña-García, A. The contribution of experimental energy facilities to the achievement of SDG in their environment: The case of IFMIF-DONES. In Proceedings of the 19th International Conference on Renewable Energies and Power Quality (ICREPQ'21), Almeria, Spain, 28-30 July 2021.

7. Nguyen, T.P.L.; Peña-García, A. Users' Awareness, Attitudes, and Perceptions of Health Risks Associated with Excessive Lighting in Night Markets: Policy Implications for Sustainable Development. Sustainability 2019, 11, 6091. [CrossRef]

8. Joint European Torus (JET) Website. Available online: https://www.euro-fusion.org/devices/jet/ (accessed on 21 October 2021).

9. IFMIF-DONES website. Available online: https://ifmifdones.org (accessed on 21 October 2021).

10. Królas, W.; Ibarra, A.; Arbeiter, F.; Bernardi, D.; Cappelli, M.; Castellanos, J.; Dezsi, T.; Dzitko, H.; Favuzza, P.; Garcia, A.; et al. The IFMIF-DONES fusion oriented neutron source: Evolution of the design. Nuclear Fusion 2021, 61, 125002. [CrossRef]

11. European Union. Agreement between the European Atomic Energy Community and the Government of Japan for the Joint Implementation of the Broader Approach Activities in the Field of Fusion Energy Research. Off. J. Eur. Union. 2007. Available online: https://eur-lex.europa.eu/legal-content/EN/TXT/PDF/?uri=CELEX:22007A0921(01)\&from=EN (accessed on 3 December 2021).

12. European Commission website/European Regional Development Fund. Available online: https://ec.europa.eu/regional_policy/ en/funding/erdf (accessed on 21 October 2021).

13. EUROfusion website. Available online: https://www.euro-fusion.org (accessed on 21 October 2021).

14. Esteban, R.; Troya, Z.; Herrera-Viedma, E.; Peña-García, A. IFMIF-DONES as paradigm of institutional funding in the way towards sustainable energy. Sustainability 2021, 13, 13093. [CrossRef] 
15. International Labour Office (ILO). Available online: https://www.ilo.org/global/lang--en/index.htm (accessed on 21 October 2021).

16. International Labour Office (ILO). Psychosocial Factors at Work: Recognition and Control; International Labour Office: Geneva, Switzerland, 1984. Available online: https:/ /www.who.int/occupational_health/publications/ILO_WHO_1984_report_of_the_ joint_committee.pdf (accessed on 3 December 2021).

17. Kalimo, R.; El Batawi, M.A.; Cooper, C.L. Psychosocial Factors at Work and their Relation to Health; WHO: Geneva, Switzerland, 1988.

18. Peña-García, A.; Hurtado, A.; Aguilar-Luzón, M.C. Impact of public lighting on pedestrians' perception of safety and well-being. Saf. Sci. 2015, 78, 142-148. [CrossRef]

19. Peña-García, A.; Hurtado, A.; Aguilar-Luzón, M.C. Considerations about the impact of public lighting on pedestrians' perception of safety and well-being. Saf. Sci. 2016, 89, 315-318. [CrossRef]

20. Peña-García, A.; Nguyen, T.P.L. A global perspective for sustainable highway tunnel lighting regulations: Greater road safety with a lower environmental impact. Int. J. Environ. Res. Public Health 2018, 15, 2658. [CrossRef] [PubMed]

21. Qin, P.; Wang, M.; Chen, Z.; Yan, G.; Yan, T.; Han, C.; Bao, Y.; Wang, X. Characteristics of driver fatigue and fatigue-relieving effect of special light belt in extra-long highway tunnel: A real-road driving study. Tunn. Undergr. Space Technol. 2021, 114, 103990. [CrossRef]

22. Slovic, P.; Flynn, J.H.; Layman, M. Perceived risk, trust, and the politics of nuclear waste. Science 1991, 254, 1603-1607. [CrossRef] [PubMed]

23. Slovic, P.; Layman, M.; Kraus, N.; Flynn, J.; Chalmers, J.; Gesell, G. Perceived Risk, Stigma, and Potential Economic Impacts of a High-Level Nuclear Waste Repository in Nevada. Risk Anal. 1991, 11, 683-696. [CrossRef] [PubMed]

24. Kleindorfer, P.R.; Kunreuther, H.C. Chapter 11 Siting of hazardous facilities. Handbooks in Operations Research and Management Science 1994, 6, 403-440.

25. Grove-White, R.; Kearnes, M.; Macnaghten, P.; Wynne, B. Nuclear Futures: Assessing Public Attitudes to New Nuclear Power. Political Q. 2006, 77, 238-246. [CrossRef]

26. Chilvers, J.; Burgess, J. Power Relations: The Politics of Risk and Procedure in Nuclear Waste Governance. Environ. Plan. A: Econ. Space 2008, 40, 1881-1900. [CrossRef]

27. Pidgeon, N.F.; Lorenzoni, I.; Poortinga, W. Climate change or nuclear power-no thanks! A quantitative study of public perceptions and risk framing in Britain. Glob. Environ. Chang. 2008, 18, 69-85. [CrossRef]

28. Troya, Z. Elaboration of a Questionnaire to Measure the Perceived Psychosocial Risks in the Environment of the Infrastructure IFMIFDONES; End-of-Degree Project; University of Granada: Granada, Spain, 2021.

29. Kleinbaum, D.G.; Klein, M. Logistic Regression, 3rd ed.; Springer: Berlin/Heidelberg, Germany, 2010.

30. Rutherford, A. Introducing Anova and Ancova: A GLM Approach; SAGE Publications: New York, NY, USA, 2001.

31. European Commission. Available online: https://ec.europa.eu/energy/eu-buildings-factsheets-topics-tree/energy-poverty_en (accessed on 3 December 2021). 